\begin{tabular}{l} 
RCCS \\
\hline Annual Review
\end{tabular}

\section{RCCS Annual Review}

A selection from the Portuguese journal Revista Crítica de Ciências Sociais

\#0 | 2009

Issue no. 0

\title{
Different as Only We Can Be. Portuguese LGBT Associations in Three Movements
}

\section{António Fernando Cascais}

Translator. Monica Varese

\section{CpenEdition}

\section{Journals}

Electronic version

URL: http://journals.openedition.org/rccsar/131

DOI: $10.4000 /$ rccsar.131

ISSN: 1647-3175

Publisher

Centro de Estudos Sociais da Universidade de Coimbra

\section{ELECTRONIC REFERENCE}

António Fernando Cascais, « Different as Only We Can Be. Portuguese LGBT Associations in Three Movements ", RCCS Annual Review [Online], \#0 | 2009, Online since 16 October 2012, connection on 19 April 2019. URL : http://journals.openedition.org/ rccsar/131; DOI : 10.4000/rccsar.131 


\section{António Fernando Cascais}

New University of Lisbon, Portugal

\section{Different as Only We Can Be. Portuguese LGBT Associations in Three Movements*}

This paper centres on the way in which the specific character of the Portuguese social formation has determined and manifested itself in the socio-genesis of LGBT associations in the last three decades. It is possible to establish a three-stage time frame which has primarily a heuristic value: the first stage, from 1974 to 1991, can be divided into two phases, before and after the appearance of the AIDS epidemic in Portugal; the second, between 1990-1991 and 1995-1997; and the third, from 1997 until now. The production of knowledge on LGBT associations has to be interconnected with two further lines of enquiry: one on its old and new detractors and opponents, and the other on the community which the associations represent and from which they emerge, with a history, an identity and a culture that explain the reasons for adherence or resistance to them.

Keywords: LGBT movement; association-building; Portuguese social formation; AIDS epidemic; gay and queer studies.

Queer criticism cannot help but slide towards diva-ism. I humbly admit and acknowledge it, honnêteté intellectuelle oblige. From the opulence of Loren (yes, that Sofia, nothing to do with the Byzantinery of Hagia Sofia), I inherited my grace, and from the valorous Dietrich (that Marlene, the one and only), like me always ready to ask what has become of the flowers, I derive my patronymic. Moi? No more closet. As queer as they make them. No more closet. Out.

Sophya Critich, in Tratado dos maus objectos (work in progress)

This article focuses on the way in which the specific character of the Portuguese social formation has determined and manifested itself in the socio-genesis of the history of the lesbian, gay, bisexual and transgender association movement (LGBT) over the past three decades. The thoughts presented here should be viewed as preliminary - and, therefore, subject to critical review - to further research, of necessity to be broadened and deepened, on the role and meaning of association-building in the history, culture and identity of the Portuguese LGBT community.

\section{On the eve of associations}

Although the community had long before set itself up, there was no organized gay, lesbian, bisexual or transgender association movement in Portugal before the Revolution of 25 April 1974. The lack of democratic freedoms precluded such events, and these freedoms are essential, albeit not the only prerequisites, for the emergence of associations. In and of

\footnotetext{
* Article published in RCCS 76 (December 2006).
} 
itself, the mere creation of formal, legal-political rights, such as freedom of association and freedom of speech, was not enough to foster the emergence of autonomous, lasting movements. These would take approximately a further two decades to materialize. Furthermore, the movement's socio-genesis followed the usual pattern to be found in Europe, and particularly in the South, arising from within the traditions and material resources of the emancipatory heritage of the left.

While still under the dictatorship, opposition parties never included gay and lesbian emancipation in their agenda. Sexuality was included only as a lateral issue, especially within the wider context of what was then known as the "Woman Question," though from the almost exclusive viewpoint of work and labour issues, and later within the context of what was understood as the "Youth Question," introduced mainly by student movements. Indeed, the scarce instances of receptiveness to the gay and lesbian movement came from a number of intellectuals and younger-generation students (not, however, from opposition veterans, especially those linked to the Communist Party), who had witnessed it directly while living in exile abroad. Similarly, the participation in political opposition activities of individuals, some of whom public figures, who were openly out or assumed to be gay or lesbian (and there were such persons) in no way meant that the generically anti-fascist, anti-colonialist, and anti-capitalist (in markedly Marxist sectors) agenda was sufficiently open to admit, not even within the confines of their "Cultural Question," any fanciful notion of gay and lesbian emancipation. Indeed, the Portuguese left was, to a very large extent, oblivious to the cultural changes that were occurring in other countries during the 1960s and 1970s, and that were essential for the renewal of European left-wing sectors.

After the 1974 revolution, Portugal's severe developmental backwardness only contributed to funnelling political action into building a social State, which, if for no other reason, reduced to a minimum the space for other types of social demand, making it also precarious and constantly under threat. Political concerns were so very other that a wall of incomprehension met the sparse echoes of gay and lesbian emancipation on the part of the radical left in May 1968 France. In the same way, or even more so, the Stonewall revolt of $1969^{1}$ received no coverage whatsoever; the same applies to the beginnings of the current

\footnotetext{
${ }^{1}$ Between 27 and 28 June 1969, the police raided the Stonewall Inn bar in Greenwich Village, New York City. The clientele was comprised mostly of gay, lesbian, bisexual and transgendered persons, many of them from ethnic minorities. This raid was met with violent protest, ensuing in urban riots over a period of days. This event triggered the growth of LGBT associations and initiatives in many parts of the world, and since then
} 
gay and lesbian movement in the USA. Besides, this had already inherited the homophile association tradition. From the point of view of associations (rather than the cultural viewpoint, since the homophile argument was used in António Botto's defence), this phase was completely unknown in Portugal, and associations only emerged in this country at a time when the gay and lesbian movement had already experienced a long evolutionary process in North-American and Northern-European countries, and was thus devoid of the self-reflective dimension it had acquired in those countries.

It is relevant to compare the Portuguese context with that of its neighbour, Spain, in the period of transition to democracy (Mira, 2004: 421-425). In Spain, there were embryonic, clandestine gay associations during the last years of the dictatorship, embedded in the antiFranco opposition and precipitated by a heightening of repression as a consequence of the Law of Danger and Social Rehabilitation passed in 1970. In addition, the Spanish gay and lesbian movement was closely associated to the renewal and cultural effervescence of the political, autonomy-seeking movements in Catalonia, as also happened, although to a lesser extent, in the Basque Country. This explains why the movement was later supported and encouraged by the governments of the Autonomous Communities. This meant that it was recognized as having a cultural capital and historical, social and political credibility, and this would allow it to affirm and establish itself early on in the democratic regime. This fact was completely unknown in post-revolution Portuguese society.

There was in Portugal nothing resembling such a left-wing political culture, receptive to gay and lesbian emancipation, that could be expected to incorporate the main gay and lesbian demands into its own agenda sooner or later. It is precisely at this stage that Portuguese history began a parting of the ways with regard to that of Spain, which with rapidly grew closer to the advanced stage of Northern-European societies. Nevertheless, the first political manifestations of the Portuguese gay and lesbian movements could not but emerge in a clearly left-wing spectrum, although, for that very same reason, bearing intrinsic ambiguities, i.e., taking as a model for political and cultural reference a sector which initially rejected it.

Stonewall and the $28^{\text {th }}$ of June have been symbols of resistance to heteronormativity. More information on this subject is available on http://en.wikipedia.org/wiki/Stonewall riots. 


\section{A composition in three movements}

In fact, a rough sketch can be drawn of a period of three stages of LGBT associations in Portugal, with the proviso that there are no rigid demarcation lines separating them: the first, from 1974 to 1990, can be divided into two phases, one preceding, the other following the emergence of the AIDS epidemic in Portugal; the second, between 1990-1991 and 19951997; and the third, from 1997 to the present day. The most pronounced break is that which separates the first two periods from the more recent one. Schematically outlined, these are:

1974-1990 - first period (with a pivotal moment in the mid-1980s)

1990-1991 - transitional period displaying mixed features

1991-1994 - second period

1995-1997 - transitional period displaying mixed features

1997 to the present day - third period.

\subsection{Primo - Largo}

The first expressions of an embryonic gay and lesbian movement came as a result of initiatives taken by a small number of individuals, who decidedly identified with left-wing sectors, though dissociated from party and trade union organizations, where gay and lesbian identities and demands found no receptiveness, and thus no opportunity for expression. It would have been completely impossible, as in fact it was, to garner for their cause the dynamics of intervention of left-wing sectors, which condescendingly discounted the contents of their demands or went so far as to refuse any form of autonomous affirmation whatsoever. To a very large extent, the parties on the left retained archaic structures moulded over the course of years of opposition to a dictatorial regime whose action was focused on maintaining the structural backwardness of the country, as well as its own role as an intermediary in world relations, as the colonial power that it was. The left-wing parties and trade unions, especially the Communist Party, endowed with an organised structure allowing them to take root straight away and to acquire far-reaching influence, defined themselves in relation to rural traditionalism and $19^{\text {th }}$ century industrialism and directly inherited a neo-realist culture that, as Eduardo Lourenço (1978) noted, conveyed an idealising populist image of the Portuguese people that prolonged and went so far as to reinforce the nationalism of the so-called Estado Novo [New State]. 
In the light of the prevailing historical-materialist model of the class struggle as a motor of history leading to the socialist society, the "Homosexual Question" could only truly be clarified in a classless society of the future. Meanwhile, the idea of a gay and lesbian struggle was, at best, perceived as divisive, since it distracted workers and militants from the fundamental objectives of their struggle, playing the enemy's game and rendering them vulnerable to it. It was also viewed as demoralising, since it would use up the energy needed for the revolutionary transformation of society, of which the proletariat was the vanguard. The struggle of gays and lesbians thus appeared as essentially demobilising, carrying ultraminority status and with no repercussions or benefit for broader struggles imbued with general social and political value, a petit-bourgeois and/or leftist illusion. In the worst case (but very widespread) scenario, same-sex matters were viewed as an eloquent manifestation of bourgeois decadence and gays and lesbians as class enemies.

Same-sex relations were even seen as a Nazi practice, and thus political perversion was conflated with sexual perversion: such was the case of the stereotype applied to the leather population. This, however, lays bare a further, insurmountable problem for the assimilation of gay and lesbian emancipation, which is the incommensurable nature of revolutionary discourse and the same-sex erotic lexicon in general, not simply the leather or other type (Cascais, 2003b). Indeed, from the viewpoint of revolutionary morality, which mythified the figure of the immaculate proletarian, the zenith of the manly virtues, the gay man was merely intelligible as the antithesis of the above. Any affirmation of sexuality was perceived as equalling the sumptuary excesses of the bourgeoisie, unbridled consumerism and the waste associated with a culture of social parasitism. This was incompatible with the frugality and restraint imposed by the discipline of work and production, and in every way contrary to proletarian asceticism, which was no more than a reproduction of Roman Catholic asceticism in secular form. Besides, and in addition to the subterranean connection with the latter, would-be revolutionary moral authority also ended up turning the prevailing heterosexism and homophobia (critical terms which did not exist at the time, and hence were unintelligible) into a virtue, thus reproducing and reinforcing them.

Taking a broader view, the demand for an identitary difference appeared suspect to the foundational egalitarianism of left-wing thought grounded on an Enlightenment matrix, which Marxism merely reinforced, and viewed as a matter that equivocally confounded the classic binary separation between the public and the private spheres. This was all the more 
so as the "Homosexual Question" (with its deplorable echoes of the "Jewish Question") was treated merely as a matter for legal regulation, and completely diluted in the generic and non-specific granting of more or fewer rights, freedoms and guarantees to citizens in general, irrespective of their sexual orientation - a completely unknown term at the time but which, in marking an irreducible specificity, is still today a source of scandal to all those who, from one end of the political spectrum to the other, regard demands for rights as calls for abusive privileges. Thus it is that, on the one hand, the outright pursuit of bourgeois respectability by the democratic left also did not foster an alternative to the (im)possibility of expressing gay and lesbian emancipation. On the other hand, on the rare occasions when this was aired in some publications linked to the radical left, it was invariably placed within the context of the "liberation of everyday life" and the "transformation of life," stripped of precise political content. Interestingly enough, or perhaps not, it is in this latter context that Portugal first saw debates on the medicalisation of homosexuality and deviance, on medicine's and psychiatry's social control role, as well as on the contesting of prevailing medical paradigms. This was a first challenge to the scientific culture of the Portuguese leftwing spheres, still under the sway of positivist republicanism and sharing every existing stereotyped representation of same-sex relations, not only with the rest of the political spectrum and society at large, but also with the University, which, at a time much preceding the emergence of gender, lesbian, gay and queer studies on the Portuguese academic landscape, was almost completely impervious to the airing of these matters. Similarly, it is a well-known fact that Portuguese feminism was unwilling to integrate lesbians in its emancipatory project (it must be stressed that "lesbian" was perceived as an insult at a time when women saw themselves as "female homosexuals" and men as "male homosexuals"), as is always reiterated by lesbians and as feminists finally admitted. These positions have recently been summed up by Amaral and Moita (2004: 101).

Thus, an absolutely decisive fact during this period was that gays and lesbians were inert prey and silent victims of social and political, cultural, media and scientific representations; the object rather than the subjects of discourse, as Michel Foucault brilliantly demonstrated (1977). Even when interviewed, it was invariably to turn them into raw material for biographical illustrations of prevailing social opinions and representations. The sole exception of the time was Guilherme de Melo, whose case was widely publicized, and is thus worthy of note, not just because nobody else had "come out," but because he was the first 
to do so in the name of a collective body - "gays" - even though such a collective had been virtually invisible until then. Both his supporters and detractors were confronted by the absence of the sole interlocutors directly concerned, gay and lesbian movements, then virtually non-existent or lacking expression, with few exceptions, ephemeral for the most part. Such was the case of the Homosexual Movement for Revolutionary Action (MHAR), created as early as May 1974, which did not survive the public reaction of General Galvão de Melo, a member of the Military Junta for National Salvation, who soon became the mouthpiece within the Junta of right-wing reaction to the revolution.

This situation, in which the gay and lesbian movement was inassimilable by the political forces of the left, remained even after the latter's influence began to wane within Portuguese society. It was in this context, further characterised by the fact that many young, political party gay militants became definitively disenchanted with the chances of their organisations opening up, that the Revolutionary Homosexual Collective appeared in 1980 (CHOR). This organisation succeeded in gathering together a few hundred persons at its inaugural session held at the head office of Culturona, an organisation devoted to cultural events, where the Collective was formed and on whose precarious support it counted. However, the Collective did not long survive it, having made its last public appearance in the Meetings: "Being (homo)sexual," hosted in 1982 by the National Culture Centre, where the first text of theoretical reflection on the movement in Portugal was presented (Cascais, 1983).

My extended emphasis on what was, at the time, the emancipatory discourse of the left has to do with the fact that it was the only one available for gay and lesbian self-expression (although it was by no means the only one with which to express same-sex orientation). However, it also raised insurmountable difficulties to such expression, which could only be overcome by means of a radical reformulation. On the theoretical plane, Michel Foucault played a major role in 'de-Marx-ifying' emancipatory language, but the reception of Foucaultian thought in Portugal at the time (Cascais, 1988, 1994) was restricted to rare academic circles and never had any direct influence on Portuguese LGBT associations. They only began to assimilate it superficially and by indirect routes much later, when the first gay, lesbian and queer studies began to appear (Cascais, 2004). In fact, this reformulation, which is far from being over in Portugal, coincided, in its early stages, with Portugal's entry into the European Community, under the premiership of Cavaco Silva, and with the outbreak of the 
AIDS epidemic. Obviously it was also, inevitably, the result of the LGBT association movement and one of its achievements.

The first phase of this movement goes from 1974 to 1991, the year that saw the emergence of the first lasting association, the Revolutionary Socialist Party's Homosexual Working Group (GTH). Nonetheless, its pivotal moment occurred in the mid-1980s, when all of the above-mentioned events took place, a moment which divides the first phase of LGBT associations into two periods, the first of which I have already described. Beyond the fact that the gay and lesbian association movement was non-existent - an aspect shared with the feminist movement (Amaral and Moita, 2004: 101) and which must be viewed in the context of the general waning of the euphoric phase of civic and cultural association movements (outside the strictly party-political sphere) - from 1982 onwards, an atmosphere of widespread ebbing began to make itself felt in an ever more pervasive manner, despite the (mainly symbolic) fact that the Criminal Code of that year decriminalised homosexuality (the previous law had long since stopped to be enforced). The most visible traces of post-1974 gay life in Lisbon virtually disappeared. This city, which had the only gay bars in business at the time and numerous meeting places, had become a reference for gay men and lesbians who flocked there from all over the country. A considerable mass of people was beginning to settle in Lisbon on a permanent basis, and the city saw the gestation of forms of sociability which would become one of the cornerstones of a community as such. Outside Lisbon, the scarce public visibility of gays and lesbians vanished completely. Far beyond any virulent manifestations of homophobic intolerance, the economic and social crisis contributed decisively to widespread disenchantment with traditional forms of political participation, but also, at the same time, to dissuading from civic activities which were too far removed from everyday concerns.

As the date drew near for Portugal's entry into the European Union, made official in 1986, a climate of expectations was generated with regard to access to European givens, not simply in terms of human progress indicators, but also - and in a vividly clear and tangible form among gay men and lesbians - in terms of cultural and legal givens, by the prospect of transposing more advanced legislation to the Portuguese legal system (Santos, 2005: 145, 176). In any event, this is a characteristic of semiperipheral societies such as the Portuguese. From 1987 on, the Cavaco Silva governments further contributed to confirming and intensifying expectations with respect to overcoming Portuguese structural backwardness, 
but also resulted in moving left-wing forces into defensive positions and confirmed the need to rethink their concepts and their practices. This fact - and it is of the utmost importance to acknowledge this - rendered them more permeable, at a first stage, to issues such as gay and lesbian emancipation, and much later provided space for its supporters within left-wing political parties (the Socialist Party, the Communist Party and the Left-Wing Bloc). Nevertheless, the so-called "leaden years," which had intensified from the first warnings of the AIDS epidemic, worsened with the news of the first cases of the syndrome in Portugal, so much so that the death of António Variações, in 1986, was experienced as a collective tragedy befalling the gay community.

\subsection{Secondo - Andante con Moto}

The AIDS epidemic was a threshold in the emergence of LGBT associations in Portugal, a generally acknowledged fact confirmed by Almeida (2004: 251), Cascais (1997: 23-24) and Santos (2005: 99-102), but it must be studied in depth. In the US, societal response to AIDS was shaped by the fight against the epidemic organised within gay communities, those most affected by it, at least initially, and also those best prepared as a result of an already considerable and substantial past in terms of community organisation and political struggle. This model, typical of central societies, spread to countries with a tradition of associations and of organised communities, and allowed for reaction to the backlash which came as a result of the initial impact of AIDS. In Portugal, exactly the opposite happened. It was in organising the fight against AIDS that associations were created, and there is little cause to speak of a backlash, as there was little or no ground to give up, nor were there opposing forces against which to resist in defence of acquired rights. The Portuguese association movement and, in general, the visibility of a gay community - which finds in it one of its pillars (and which, therefore, is not complete without it) - gained strength within the broader process of the fight against the AIDS epidemic. It began to include itself in this dynamics, using it to great advantage before it was able to become autonomous. It is to this extent that the socio-genesis of gay associations in Portugal confirms the semiperipheral situation of the Portuguese social formation, initially theorised by Boaventura de Sousa Santos $(1992,1996)$ following up on Immanuel Wallerstein, and whose application to the LGBT community was made by Ana Cristina Santos (2005). Besides, the emergence of gay 
associations within the context of the fight against the epidemic is not exclusive to Portugal; it is rather common to and typical of other semiperipheral societies.

In Portugal, from early on, gay participation could be seen in NGOs combating AIDS, but these were the outcome of initiatives taken by elite groups of health experts and professionals, by psychologists and the occasional public figure. This situation was not entirely without cost, given that the double membership of some gay association leaders in these NGOs gave rise initially to a certain number of situations imbued with ambiguity and conflict of interests whenever somewhat paternalistic attitudes on the part of NGOs led to interference in association politics. We are dealing here with a model of civic participation which has been well known at least since Tocqueville, who described the way reformist initiatives and political intervention in general sprang in Europe from enlightened elites (political, economic, social and cultural), who behaved as representatives of third parties who had delegated their own interests to them, whether formally or tacitly. In contradistinction, in the grassroots model prevailing in the US, the protagonists were associations of anonymous citizens actually representing themselves by electing their delegates from among their peers.

In Portugal, the discourse of the fight against AIDS was headed by third parties with no links to the gay community, namely by the medical class, whose authority, both scientific and social, remained intact. The fight against discrimination against HIV-positive individuals and the sick uniformly stressed the common good, without taking on the role of mouthpiece for their special interests and without even referring to them explicitly, rather diluting them in the broader context of human and citizenship rights. Besides, the time it took for the epidemic to be clinically diagnosed in Portugal made it possible, especially where the medical profession, as also the political caste and the media were concerned, not to repeat the ravages caused elsewhere by the initial categorisation, later revised, of "groups at risk," the ranks of which were swelled by gay men.

All this contributed towards dissociating the fight against AIDS from emancipatory gay discourse, which in the end contributed towards its acceptance and to preparing the initially neutral reaction to the association movement, whose stance in Portugal was never as radical as that of groups such as ACT-UP. It further contributed to the concept of prevention as a social responsibility, held by many sectors of Portuguese society, beyond the medical profession, from political power structures to NGOs and the media, and to concerns with 
political correctness, until then almost unheard of with regard to gays. This resulted in a kind of official acknowledgement of the existence of a gay and lesbian community and a quasisanctioning of its sexual behaviours - a visibility and sanction whose importance can also be measured by the outraged reactions of certain bodies such as the Roman Catholic hierarchy. Although no less virulent, the latter's doctrinal positions thus became subject to public criticism, to reiterated challenges, and the Church was placed at permanent risk of entrenchment in defensive and rigid attitudes, generally perceived as fundamentalist and fanatical. Indeed, the homophobia and heterosexism traditionally to be found in Portuguese society were in equal measure met head-on and silenced for the first time by an authoritative discourse conveyed in the fight against AIDS. Finally, the emerging association movement could thus avail itself of a capital of respectability - i.e. as a credible interlocutor - which it would not otherwise have gained and which lent it an emancipatory dynamics that has remained essentially uninterrupted to this day. Furthermore, this dynamics reduced the room for manoeuvre, public receptiveness and efficacy of its enemies, who, nonetheless, remained, but were only able to flex their muscles again from the moment when the association movement raised other banners with enough strength to defend these appropriately, which did not really happen before 1997. From the point of view of the time frame I presented at the beginning of this article, the process I have been describing takes us approximately from the emergence of the AIDS epidemic until 1990-1991, when the lesbian magazine Organa and the Homosexual Working Group were founded. I take this as an arbitrary milestone that concludes the process of the initial impact of AIDS on the community.

Not for a moment should the AIDS epidemic be understood as being only the kairos moment for Portuguese gay (and LGBT) associations. This unique opportunity took its toll in blood with an extensive martyrology, whose importance has never been fully appreciated by the social science research of a country possessing a mythic-religious heritage as does Portugal and on which I am unable to dwell here. Viewed very superficially, I would suggest that this is a phenomenon that, par excellence, deprives adversaries of arguments in a culture, such as the Portuguese, in which public statements of conviction have less to do with doctrinaire debate and rational argumentation than with heroic example-setting (with its counterpart, aesthetic seduction). Paradoxically, or perhaps not entirely, this is a factor (in addition to others cited) that possibly explains the peculiar way in which Portugal 
witnessed phenomena of such magnitude and of such profound repercussions elsewhere (especially in the US), such as discrimination against HIV-positive individuals and the sick, victim blaming, or the health scare which always accrues to moral scare. Perhaps too succinctly and subject to later, in-depth study, I would further suggest that the features of Portuguese society's traditional homophobia became quantitatively more pronounced in tone and in intensity, but remained qualitatively unaltered. In other words, the terms of the anti-gay and lesbian battery of arguments remained essentially the same, and nothing resembling the wave of persecution in the immediate aftermath of the AIDS epidemic occurred here. On the other hand, this confirms the archaic features of Portuguese society: the gay community had not moved beyond the traditional stage of marginalisation (it was not acknowledged as equal, or even as a valid interlocutor), objectification (it had no control over the social representations produced about it and was not the subject of public affirmation or action), invisibility (it was stripped of self-expression, of representatives, and no relevant persons or events were associated to it) and resignation (it only adjusted, as an imperative for survival, to the marginal and clandestine situation to which it was relegated). This also meant that, for the gay community, the AIDS epidemic worked as a type of outing, both of individuals in and of themselves (when affected by the disease) and of the community in general. Association-building was the core of the community's response to the challenge embodied in such an outing. The AIDS epidemic afforded gays (and later the LGBT community) the opportunity to rise up against ancient oppression. Indeed, after the first impact of the AIDS epidemic in Portugal (between 1984-1986 and 1990-1991), the maturing process of association-building, as a reaction to the above impact, occurred approximately between 1990-1991 and 1995-1997, and took on crucial importance in the time frame I have proposed. It was during these years (between 1990 and 1997) that the transformation I have described took place. The years 1990-91 and 1995-1997 were years of transition between the periods coming immediately before and immediately after, during which - respectively features of the preceding period are maintained and features of the subsequent period begin to appear. And it was the first time that an agonistic situation - in which a hegemonic pole crushed the dominated pole to such a degree that the very existence of the confrontation could be denied by the former - found a resolution favourable to the gay community in Portugal, since the tragic episode of a similar confrontation in $20^{\text {th }}$ century 
Portuguese history, that which opposed António Botto and Judith Teixeira (and, surely, Fernando Pessoa) to the homophobia of the Estado Novo (Cascais, 2003a).

Directly affected by AIDS, the gay community was at the same time the one that was most changed by it. As it happens, in the central countries, the epidemic contributed to precipitate a fundamental change of strategy: from a struggle for sexual citizenship centred on the demand for rights regarding practical conduct (rights to sexual activity, to pleasure, to the body) and identity (the right to self-definition, to expression, to self-fulfilment) to a struggle for sexual citizenship underscoring rights with regard to relationships (the right to consent, to free choice, to institutional acknowledgement of relationships, such as domestic partnerships and marriage, and related rights such as medically assisted pregnancy and adoption). At the same time, at least a further three relevant changes took place in Portugal: a shift from predominantly essentialist argumentation to a constructionist emphasis in the approach to identities, peaking in queer thought; a critique of the hegemony of gay identity and subsequent inner fracturing of the community through the separatist affirmation, firstly, of lesbian identity and, close on its heels, of bisexual and transgender identity (giving rise to the current LGBT jargon, whose pertinence I will not analyse here); a change in the affirmation of difference, of the community's irreducibility and singularity - which finds its highest expression in the ghetto as a type of self-discriminating "liberated zone," following the US ethnic model (which would later be exported to the rest of the world) - to a logic of growing integration of specific gay, lesbian, bisexual and transgendered lifestyles. This aimed at crumbling the more or less rigid frontiers between the ghetto and the larger society, but, as Foucault long before diagnosed, it is also more difficult than entrenchment in the ghetto. From the alternative lifestyles which can only germinate in the ghetto, that is to say, an alternative in difference, we shift to an alternative in integration, in equality, in parity and in indifference. Such is the case of marriage and adoption, which for gays and lesbians signify building a lifestyle grounded on remaking what Anthony Giddens (1993) called the pure relationship. However, this only became possible as a result of a long process of building identities and consolidating LGBT communities, which only happened in Portugal in a superficial way.

The association movement in Portugal emerges within this context of a shift in culture and identities in international LGBT communities, but, as can easily be seen, with understandable difficulties in assimilating it. We have now arrived at the last period, which 
began to take shape in the years 1995-1997, a triennium of transition which retained features of the preceding phase and which has been fully constituted from the latter date to the present time.

\subsection{Terzo - Allegro ma non troppo e grazioso}

Within the time frame I have established, which has primarily a heuristic value, the only clearly perceptible exception was the Homosexual Working Group, whose early stages are far closer to the spirit of MHAR (Homosexual Movement for Revolutionary Action) and CHOR (Revolutionary Homosexual Collective) than to post-1995 associations. However, it was clearly different from these two organisations inasmuch as it emerged within a political party, the Revolutionary Socialist Party, which was initially influenced by Trotskyist ideology. The history of the Homosexual Working Group, which would become firstly the LGBT Group embedded in the Left-Wing Bloc, when the Revolutionary Socialist Party entered this political party, and later the Pink Panthers - Front to Combat Homophobia (2004), now independent of party political structures, significantly illustrates two interconnected facts: first, that gay and lesbian emancipation had been for a very long time 'pushed' towards the revolutionary left and tended to express itself in the radical terms of outsider refusal of the system, due in large measure to the impossibility or reluctance on the part of gays and lesbians in the social, cultural and political elites to affirm themselves publicly as such; second, the extent to which party membership or party political affinities were the nemesis of association-building and a key reason for revising the emancipatory discourse I referred to at the beginning, by virtue of the need to move beyond party political in-itself-ism and of not alienating the LGBT community itself, which does not identify with the defence of its interests in such terms.

Visibility and the consequences of association-building are precisely what constitutes, in essence, the third and current phase, since 1995-1997, after which the LGBT community is represented by its own members, becomes a historical subject endowed with its own voice, and an interlocutor both vis-à-vis its allies and its opponents. These are the years when associations burst forth: ILGA-Portugal, with the opening of its Gay and Lesbian Community Centre (1997) in Lisbon, Opus Gay (1997) and Clube Safo (1996), as well as Portugal.Gay.pt (1996), an internet-based organisation, Korpus magazine (1996), the first publication to attain the longevity of a decade, the Lisbon Gay and Lesbian Film Festival, with a similar 
longevity since its first edition in 1997, and the radio programme Alternative Lives, since 1999, the unique occurrence of access to the media in the history of Portuguese associations. Also during the course of these years, the left-wing party political sphere represented in parliament and in local government finally became receptive to the community's demands, peaking in the period of João Soares's term as mayor of Lisbon. The overall receptiveness and even overt goodwill of some of the media round off this favourable period, lasting at least until late 2004. It was in this context that the first Pride Festival took place (1997) - later held in the emblematic Lisbon Municipality Square - as well as the first Pride March (2000). The dynamics of growth continued until at least 2002, when the first Pride Week was held, and led to the creation of a number of other associations: Não te Prives [Don't deprive yourself] - Group for the Defence of Sexual Rights (2001), ex aequo Network (2003) directed towards young LGBT between the ages of 16 and 30, @t Association for the Study and Defence of Gender Identity (2003), Grupo Lilás, and NÓS [Ourselves] - University Movement for Sexual Freedom, between 2000 and 2003, Grupo Oeste Gay, between 2000 and 2005, and Coisas do Género between 2001 and 2003, or even associations such as Muralha [The Wall] and the Portuguese Association for Male Homosexuality (2006), which was essentially created as a gesture of public demarcation from the LGBT movement.

The following points should be stressed: the expansion of the associations' influence beyond the large urban centres of Lisbon and Oporto, either through the activities they promoted, or because they organised as networks; the internal differentiation of the associations, of which the most prominent example is that of the ILGA Women's Group (1998), which later became the Group for Lesbian Intervention and Reflection (2000); the capacity for hosting supranational events such as the $17^{\text {th }}$ Annual Conference of the International Lesbian, Gay, Bisexual and Transgender Youth and Student Organisation (2003) by the ex aequo Network; the $24^{\text {th }}$ ILGA-Europe Annual Conference (2002) by Opus Gay; the launch of the World Day for Combating Homophobia (2005), at which its founder, LouisGeorges Tin, was present, an initiative of the association Janela Indiscreta [Indiscreet Window], which in the meantime formally took over the organisation of the Lisbon Gay and Lesbian Film Festival; the recognition of associations by national representatives of world organisations such as the Women and LGBT Nucleus of the Portuguese Section of Amnesty International, as well as the active participation of national associations in international 
events such as the national edition of the Women's World March (2000) and the First Portuguese Social Forum (2003). Articulation with academic reflection and research, although still rare, was successfully attempted by Clube Safo, which co-organised the first Lesbian Workshops (2002) with the Higher Institute for Applied Psychology; the first International Congress of Gay, Lesbian and Queer Studies, "Cultures, Visibilities, Identities" (2005), was jointly promoted by the association Janela Indiscreta, the Franco-Portuguese Institute and the Centre for Communication and Language Studies of the New University of Lisbon; and a number of initiatives were launched by Não te Prives in cooperation with the Centre for Social Studies, Coimbra University. Last but not least, Portuguese LGBT associations became prime interlocutors of party political organisations and governmental bodies in what concerns the drafting of legislation, although they have had to counter the condescension of the latter with the definition of their own agendas, of which a salient example was the recent (2005) launch of the pro-marriage rights campaign.

Although this period displays a number of significant achievements on the part of the LGBT association movement, namely in terms of legal rights, the convergence of LGBT community interests and political-institutional interests was not uninterrupted, and this means that those achievements are not irreversible. Indeed, the emancipatory dynamics remains until the present time, but is confronted by two facts: association-building has reached what seems to be a limit in growth; this, in turn, has coincided with (but is not an effect of) the beginning of an anti-emancipatory reaction and of an adverse political and media environment which configure a new agonistic situation, not dissimilar to that which initially prompted it.

In the light of the questions raised by the current situation, the associations are faced with a double necessity, as much cognitive as political: that of acquiring in-depth knowledge of the community they represent or from which they sprang, with its history, its identity, its culture, but also its internalised homophobia and the shape it takes to the detriment of associations themselves, re-building its memory as a form of resistance to non-participation (Gil, 2004), so fatal in Portuguese society and culture; and that of recognising its detractors and enemies, both old and new, all the more so as they henceforth define themselves in relation to its visibility and achievements. 


\section{Closing remarks}

Associations were not built up overnight, not in Portugal, nor anywhere else. They did not erupt onto a historical, social and cultural tabula rasa. In Portugal, associations, as well as all the expressions of LGBT cultures and identities, are faced with a history of oppression, denial and social control, which lent shape to the characteristics of the Portuguese social formation that are adverse to them.

The first challenge facing gay, lesbian and queer theory, as well as the social and human sciences, is to study associations, which still largely represent a true terra incognita. The second, greater challenge is the rebuilding and recovering of the other historical heritage to which the present LGBT communities are the direct heirs: gay and lesbian cultural expressions, both erudite and popular, forms of sociability, the erotic lexicons and the modalities of "pleasure usages" which were sedimented historically. The fruits of such work would represent an invaluable acquisition for the main actors in LGBT associations in Portugal. Over the past four decades, the latter's social history constitutes the other major cognitive challenge towards which this article offers a first contribution.

From it, we can conclude, briefly, that LGBT associations would simply not have been possible before the establishment of a democratic regime in 1974 , but the latter, on its own, was not sufficient for their emergence, and it would take about three decades to develop associations in the Portuguese semiperipheral society. The socio-genesis of the LGBT movement followed the pattern common to Southern European countries, developing from the traditions and the material resources of the emancipatory heritage of the left. However, the incipient expressions of a gay and lesbian organisation movement faced insurmountable barriers in attempting autonomous organisation, openly stated political support and the inclusion of their interests in the agendas of political parties and trade unions until the beginning of the 1990s.

The process of reformulating political discourse which finally made it possible for gay and lesbian emancipation to become assimilable by these spheres ran parallel with, and was conditioned by, the premiership of Cavaco Silva (absolute majority of the Social Democrat Party in 1987), by the entry into the European Union (made official in 1986) and by the AIDS epidemic (the first cases were detected in 1984-85). That is to say, respectively, by the modernisation of left-wing parties and cultures (which assumed a defensive stance), by the replacement of a revolutionary model for social change with expectations for access to 
European economic, social and legal-political givens, and by the inclusion of segments of the gay community directly affected by the AIDS epidemic, who had nothing to lose, in the NGOs fighting AIDS, a process which lent them the necessary dynamics and legitimacy.

LGBT associations in Portugal thus gained momentum within the context of a wider process of anti-AIDS struggle, getting involved in it and taking advantage of it in a remarkable way, until they were able to gain autonomy from it and build up their own dynamics. To this extent, the socio-genesis of LGBT associations confirms the semiperipheral position of Portuguese society. This situation explains why it was only from the mid-1990s that Portuguese LGBT associations acquired a status identical to that of its European and North-American counterparts, embodied in organisations representative of the community itself, in social and media visibility, in credibility and in the ability to put pressure on partypolitical organisations and State institutions, and finally, in a political agenda of its own.

Translated by Monica Varese

Revised by Teresa Tavares

\section{References}

Almeida, Miguel Vale de (2004), Outros destinos. Ensaios de Antropologia e cidadania. Oporto: Campo das Letras.

Amaral, Ana Luísa; Moita, Gabriela (2004), "Como se faz (e se desfaz) o armário: Algumas representações da homossexualidade no Portugal de hoje," in António Fernando Cascais (ed.), Indisciplinar a teoria. Estudos gays, lésbicos e queer. Lisbon: Fenda, 99-115.

Cascais, António Fernando (1983), “Como quem não quer a coisa," Fenda (In)Finda, 7, 9-17.

Cascais, António Fernando (1988), "Autenticidade e razão decisória em Michel Foucault," Revista de Comunicação e Linguagens, 6/7, 71-83.

Cascais, António Fernando (1994), "Paixão, morte e ressurreição do sujeito em Michel Foucault," Revista de Comunicação e Linguagens, 19, 77-117.

Cascais, António Fernando (1997), "Da virulência." Preface to António Fernando Cascais (ed.), A Sida por um fio. Lisbon: Editorial Vega, 7-25.

Cascais, António Fernando (2003a), "Portugal," in Georges-Louis Tin (ed.), Dictionnaire de I'homophobie. Paris: Presses Universitaires de France, 328-330.

Cascais, António Fernando (2003b), "Sexo para que te quero?" Interact. Revista Online de Arte, Cultura e Tecnologia, 9. Available in http://www.interact.com.pt.

Cascais, António Fernando (2004), "Um nome que seja seu: Dos estudos gays e lésbicos à teoria queer," in António Fernando Cascais (ed.), Indisciplinar a teoria. Estudos gays, lésbicos e queer. Lisbon: Fenda, 21-89. 
Foucault, Michel (1977), História da sexualidade, 1: A vontade de saber. Lisbon: Edições António Ramos.

Giddens, Anthony (1993), The Transformation of Intimacy. Sexuality, Love and Eroticism in Modern Societies. Cambridge: Polity Press.

Gil, José (2004), Portugal, hoje. O medo de existir. Lisbon: Relógio d'Água.

Lourenço, Eduardo (1978), O labirinto da saudade. Psicanálise mítica do destino português. Lisbon: Publicações Dom Quixote.

Mira, Alberto (2004), De Sodoma a Chueca. Barcelona: EGALES.

Santos, Ana Cristina (2005), A lei do desejo. Direitos humanos e minorias sexuais em Portugal. Oporto: Afrontamento.

Santos, Boaventura de Sousa (1992), O Estado e a sociedade em Portugal (1974-1988). Oporto: Afrontamento.

Santos, Boaventura de Sousa (1996), Pela mão de Alice. O social e o político na pósmodernidade. Oporto: Afrontamento. 